\title{
Quality of Life in Adult Hypopituitary Patients Treated for Growth Hormone Deficiency ${ }^{\S}$
}

\author{
Marianne Klose, Åse Krogh Rasmussen and Ulla Feldt-Rasmussen ${ }^{*}$
}

Medical Department of Endocrinology Rigshospitalet, University of Copenhagen, Denmark

\begin{abstract}
Growth hormone (GH) affects all organ systems and several studies have also indicated an influence on health related quality of life (QoL). Assessment of QoL is therefore considered as one of several valid indicators of whether or not treatment with GH is beneficial. Two main types of QoL measures are generally used: disease-specific and generic. A combination of the two is generally advocated as they seem to be complementary. Methodologically, questionnaires must be correctly validated in the relevant context of language and a sufficient population based reference group.

In this review, the previously published studies on the effects of GH replacement therapy on QoL in adults will be scrutinized. Although many of the studies on the influence of GH replacement on QoL assessment are either having a too short follow-up period, are uncontrolled, or using supra-physiological GH doses or inappropriate QoL instruments, there is a growing body of evidence for impaired QoL in GH deficient patients with improvement or normalisation after GH replacement.
\end{abstract}

Keywords: QoL, GH deficiency, pituitary, patient reported outcome, generic, disease specific.

\section{INTRODUCTION}

Growth hormone $(\mathrm{GH})$ exerts pleiotropic effects on all cells and organs, and several studies have also indicated an influence on health related quality of life (QoL). The effect may be through central mechanisms or secondary to GH effects on metabolic, cardiovascular, immune, reproductive, bone and/or muscular functions. The typical phenotype of GH deficiency displays as part of the syndrome a reduction in many classical QoL measures (Table 1). QoL has been defined by the World Health Organization as 'the state of complete physical, mental, and social well-being and not merely the absence of disease or infirmity' (WHO, 1947). Thus, QoL is a difficult concept to quantify and measure across disease states. GH was previously only used therapeutically to correct growth and height deficits in children. The access to recombinant $\mathrm{GH}$ opened for the possibility to treat adults with GH deficiency. However, GH therapy remains expensive, and it is therefore mandatory to document both safety and efficacy of the treatment. Studies have generally shown a beneficial effect of GH replacement on features of $\mathrm{GH}$ deficiency. However, although not documented GH replacement has also been suspected to potentially worsen or induce cancer by stimulating growth of cells $[1,2]$.

*Address correspondence to this author at the Medical Department of Endocrinology, PE Rigshospitalet, Blegdamsvej 9, Copenhagen, DK-2100, Denmark; Tel: +45 35452337; Fax: +45 35452240;

E-mail: ufeldt@rh.dk

${ }^{\S}$ Part of information included in this chapter has been previously published in The Somatotrophic Axis in Brain Function 2005, Pages 237-248.
Whether or not GH deficient adults should be offered GH replacement therapy is still controversial. An improved body composition to a more favorable state has been highly reproducible in all studies on the effect of GH replacement in patients with hypopituitarism, but the capacity of $\mathrm{GH}$ replacement to improve other variables such as lipid profile, blood pressure, morbidity and mortality have been more controversial. Measuring QoL is nonetheless one of several highly acknowledged indicators of the treatment effects of $\mathrm{GH}$, as is commonly noted in consensus statements of official bodies. The American Association of Clinical Endocrinologists (AACE) states that "Replacement therapy should be monitored carefully ..... and special emphasis should be placed on perceived and objectively measured benefits and adverse effects" [3].

Also, National Institute for Clinical Excellence [4] stated in the technology appraisal for GH replacement therapy in adults that decreased QoL was a prerequisite for starting GH replacement. The decreased QoL should be documented in the individual patient by the disease specific questionnaire on quality of life assessment of growth hormone deficiency of adults (AGHDA) [5]. Improvement of the AGHDA scores in the individual patient was further required after 9 months (3 months of titration followed by 6 months of stable therapy) in order to decide on continued reimbursement of the GH replacement therapy. This underlines the importance of physicians having access to reliable routine measures of QoL, with sufficient accuracy, precision, sensitivity and specificity of the assessment.

\section{QOL MEASUREMENTS}

The assessment of QoL, considering the broad definition by $\mathrm{WHO}$, is an attempt to determine how a disease condition 
or its treatment relate to particular important domains of life, either to people in general or to people who have a specific disease condition $[6,7]$. Most concepts of QoL emphasize the effects of illness on physical, psychological and social functioning [8]. In clinical research, many patient-reported measures of QoL are becoming increasingly accepted as valid indicators of treatment effects [9, 10]. Thus, patientreported QoL measures are becoming increasingly accepted also in the assessment of patients with GH deficiency, and a number of different questionnaires have been used to quantify the effect of GH therapy on QoL in adults [11] (Table 2).

Table 1. Symptoms and Signs of Adult Growth Hormone Deficiency

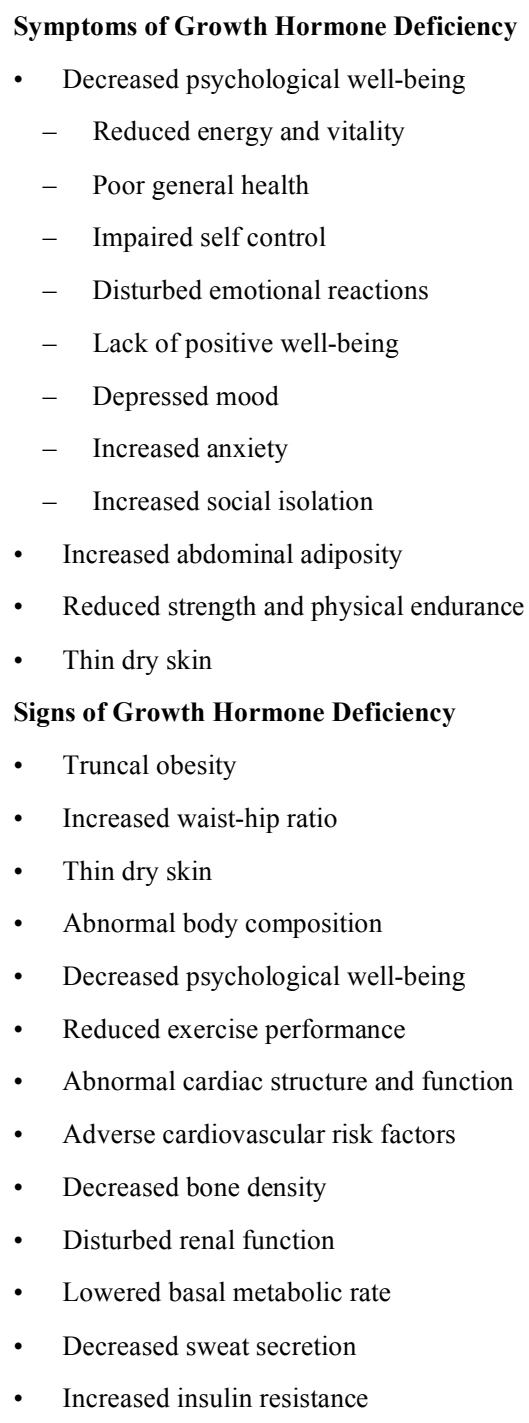

Currently, two main types of QoL measures are used: disease specific and generic. Older studies have usually relied on generic questionnaires measuring the total burden of disease such as the Short Form 36 (SF-36) Health Survey (consisting of 36 items assessing eight health dimensions: physical functioning, role limitations due to physical health,
Table 2. Tests Used to Assess Health Related Quality of Life and/or Psychological Well Being (Modified and Updated from Hull and Harvey [11] with Permission from the Authors)

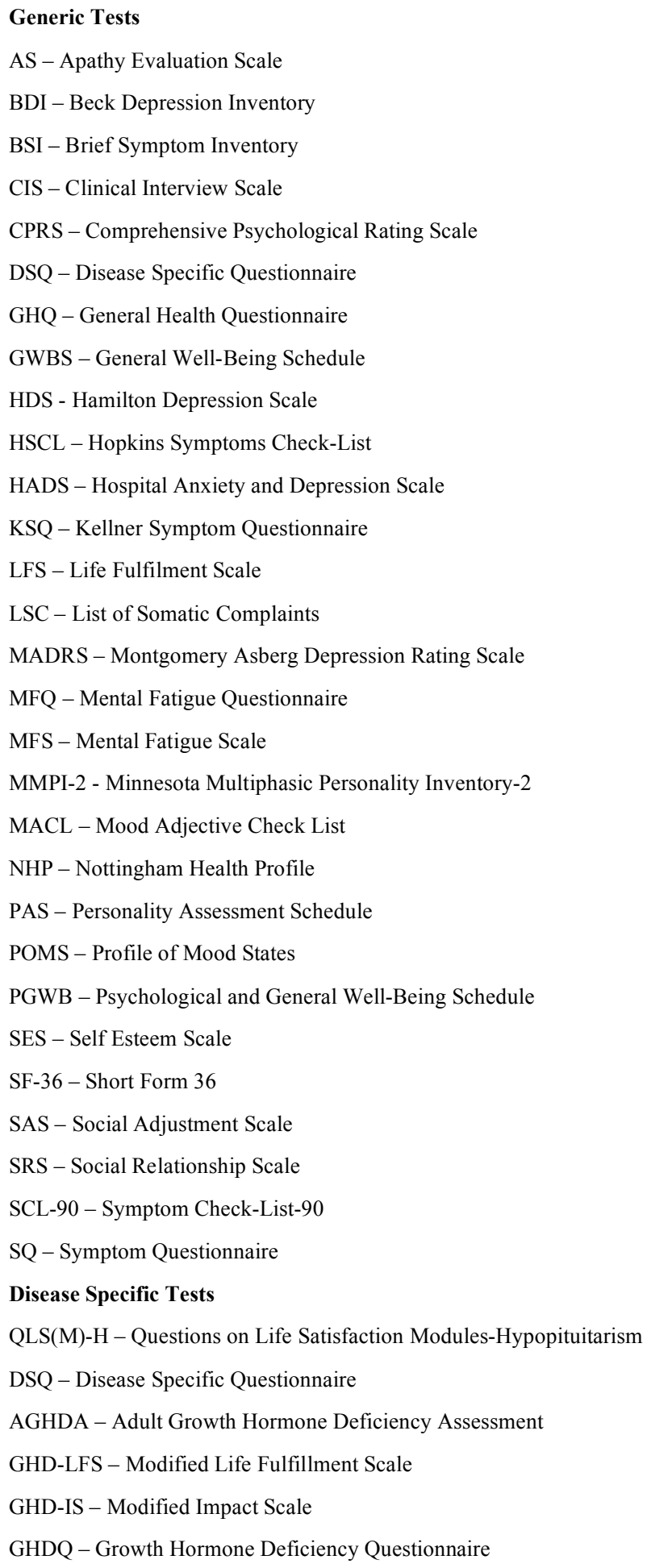

bodily pain, general health perceptions, vitality, social functioning, role limitations due to emotional problems and mental health), the Nottingham Health Profile (NHP) 
(consisting of 38 items assessing six dimensions of health problems: physical mobility, pain, social isolation, emotional reactions, energy level, and sleep) or the General Health Questionnaire (GHQ). In theory, though, disease-specific questionnaires demonstrate greater sensitivity than generic ones. The questions formulated in a disease-specific health survey point directly to the symptoms that are typical of GH deficiency and address problems specific to or common among patients with GH deficiency. The Qol-AGHDA was the first available GH deficiency-specific questionnaire [5]. It was developed through in-depth interviews with hypopituitary adults, and subsequently translated into different languages and validated in each language among hypopituitary adults assumed to be $\mathrm{GH}$ deficient. Based on these validations it was adopted for cross-cultural use [12], and it has therefore been used extensively in multinational studies.

The item questions in this needs-based questionnaire are such as: 'It is difficult for me to make friends'; 'I often forget what people have said to me'; 'I find it difficult to plan ahead'; 'I have difficulty in controlling my emotions'; 'I often feel too tired to do the things I ought to do'.

Disease-specific and generic measures are often combined as the obtained information is complementary [6]. Thus, no single QoL instrument has sufficient sensitivity, specificity and accuracy to be able to discriminate completely between the outcome of the patients compared to a control population. Individual clinical assessment therefore still remains of paramount importance [13]. A major problem in comparing data from various studies on QoL in $\mathrm{GH}$ deficient adults is the fact that the studies are very different from many different points of view, and therefore not directly comparable. First of all, many of the questionnaires have not been correctly validated and tested in the language relevant for the study in question and very often the studies have not indicated if a sufficient country specific population based reference group had been used as comparison. Unfortunately, this is true for both generic and disease specific QoL measures. As to $\mathrm{GH}$ deficient populations treated with $\mathrm{GH}$ replacement there is a marked difference in physician attitude towards whether the criteria set down by Growth Hormone Research Society (GRS) should be followed or not [14], and thereby published studies can also for that reason harbour severe biases in the comparability of populations of GH deficiency.

Also, variable national official criteria such as those set by NICE in UK may create a basis for further population differences, since the $\mathrm{UK}$ requirements for $\mathrm{GH}$ replacement therapy are presence of very severe and long-lasting GH deficiency, while an accepted GH stimulation test according to GRS criteria is sufficient for GH reimbursement in e.g. Denmark and Sweden. Other countries even allow treatment of patients with partial deficiency and not only with severe $\mathrm{GH}$ deficiency. Given the establishment of a general positive attitude towards treatment of GH deficiency when clinically appropriate, a low Qol should no longer be present in the majority of the patients, because patients are now treated as soon as they develop GH deficiency (e.g. soon after pituitary surgery) and therefore do not develop the full-blown phenotype of GH deficiency. Considering above mentioned differences in $\mathrm{GH}$ reimbursement policies, this augment only holds true for some countries. In the overall comparison of studies on the effects of $\mathrm{GH}$ replacement it also has to be remembered that all the very early randomised placebocontrolled trials used weight-based and supraphysiologic i.e. acromegalic doses of $\mathrm{GH}$, while all current treatment regimens aim at titrating the $\mathrm{GH}$ dose to an insulin-likegrowth factor-I (IGF-I) Z-scores (=standard deviation scores, SDS) between 0 and +2 SDS. This more physiological monitoring regimen puts a high demand on the composition of the reference population for IGF-I measurements in each laboratory in order to calculate the Z-scores. Thus, above mentioned complexity has to be considered in any comparison of the published results on previous and present treatment regimens.

\section{QOL IN GROWTH HORMONE DEFICIENT ADULTS}

\section{A. At Baseline}

Most clinical studies have demonstrated that symptoms such as social isolation, mental fatigue, increased emotional stress, and decreased energy, life satisfaction and self-esteem are more prevalent in a GH deficient population (reviewed in Hull and Harvey [11]) consistent with the typical features in patients with severe GH deficiency (Table 1). However, three studies using generic rather than disease specific tests for measurement of QoL failed to detect any difference in QoL between $\mathrm{GH}$ deficient individuals and the normal population [15-17]. Zenker et al. [16] compared the outcomes of the questionnaire answers with the level of IGFI and the $\mathrm{GH}$ peak response from either a GH-releasing hormone test or an insulin tolerance test. They stated that the absence of any relationship between GH deficiency severity and level of apathy/depression/ psycosomatic complaints suggested unspecific impairments not related to $\mathrm{GH}$ deficiency. They suggested that the somatic improvements from $\mathrm{GH}$ replacement would lead to symptomatic improvement and thereby be secondary rather than primary. Furthermore, they advocated that the indication for $\mathrm{GH}$ substitution therapy should mainly be based on the presence of somatic symptoms of GH deficiency and not be based on psychological impairments alone.

It must be emphasized that their results and conclusions were based on rather small groups of patients, i.e. the studies were not likely to have sufficient power for a statistical significance. They are further in contrast to a number of other studies e.g. McMillan et al. [18]. They performed a double-blind placebo-controlled trial with discontinuation of $\mathrm{GH}$ replacement in 9 patients with severe $\mathrm{GH}$ deficiency, randomised to continue $\mathrm{GH}$ replacement while $\mathrm{GH}$ was discontinued in 12 patients for 3 months (placebo). Despite the rather low number of patients in the study, they found a significant difference between the groups in scores for SF36, HDQoL, and by interview most patients identified correctly treatment with GH or placebo, respectively. These authors concluded that withdrawal of $\mathrm{GH}$ treatment from adults with severe GH deficiency had detrimental 
psychological effects. Such contrasts in conclusions from the various studies might be due to heterogenous patient populations and their comparative control groups or populations, as well as differences in the methods for measurement of QoL (Table 3). Variable inclusion in the studies of childhood and adult-onset GH deficiency patients, by virtue of their underlying pathology, is a good candidate for variability in results. Adult-onset GH deficiency is often associated with other pituitary hormone deficiencies which may interfere in the scores of QoL in these patients, while GH deficiency in children is very often isolated. In addition, childhood onset GH deficient patients may have a series of other psychological problems related to the disease in childhood, including poor growth and low adult height. The importance of GH deficiency may be evidenced by studies demonstrating that even though appropriate replacement of all hormones except GH to pituitary insufficient adults was done, QoL was not normalized [16, 19].

A geographic difference in QoL has been demonstrated in patients with GH deficiency [20]. A specific reason for that is not quite clear, since the same questionnaire (AGHDA) was used in all countries that study, and the questionnaire had been validated correctly in GH deficient patients from the different countries and across languages. However, possibly an assessment of QoL measures by any questionnaire should also in each country be validated in and compared to the normal population, and not only in GH deficient patients, in order to correct for country differences [21]. The following examples seem to substantiate this statement. Koltowska Häggström et al. [21] showed that among approximately 1000 members of the general population in England and Wales the mean AGHDA score for women was 7.0 and for men 6.3. Patients with GH deficiency from the same area had scores approximately 7 higher (poorer QoL), and significantly different from the healthy general population mean. A similar study in Spain also found a significant difference between healthy members of the general population and Spanish patients with GH deficiency the scores for both groups were, however, much lower (i.e. better QoL) than those from England and Wales. The same was the case for German and Swedish patients [22]. Similar differences between countries with UK displaying the poorest QoL in both controls and patients with GH deficiency were also shown by use of another disease specific questionnaire (QLS-H) [23]. Thus, it is clear from these studies that language validation even of disease specific questionnaires is insufficient to avoid bias, and comparison with QoL measures in the background population is essential.

\section{B. Effects of GH Replacement Therapy on QoL in Adults}

In most of the clinical studies, both generic and GH deficiency-specific QoL measurement tools have indicated that GH replacement therapy enhanced QoL (reviewed in Hull and Harvey [11], and expanded in Table 4). Of these studies, half were fully or partly placebo-controlled [24-38], while the remaining were non-placebo-controlled [39-55].

However, some of the fully or partly placebo-controlled studies $[15,24,25,30,34,56-59]$ failed to show any effect of GH supplementation on QoL in at least one of the $\mathrm{QoL}$ scales, and demonstrated normal QoL parameters compared to control populations. Generally, the studies were very heterogeneous and reporting very few patients (Table 4). Only few studies have applied a fully placebo controlled double blinded approach - all of them of rather short duration $[15,24,28,30,36,37]$. Fifteen of the studies combined a placebo controlled approach followed by open treatment, and yet other 21 applied an open trial approach only (Table 4). The dosages used were also extremely variable and depended largely on when the study was performed. Thus, in the early days of $\mathrm{GH}$ replacement therapy the patients were severely overtreated because the dose used was based on experience from childhood treatment and based on weight and/or surface, as opposed to the current dose titration in each individual patient according to the age-adjusted IGF-I concentration.

The very variable designs of all the controlled trials almost without any common denominator, unfortunately also precludes the performance of a meta-analysis of the results.

Among the open trials some need a special comment. Three studies looked into very long term effects. Two of the studies $[42,46]$ showed an increase in QoL with time during $\mathrm{GH}$ replacement. Follin et al. (2010) did not find any significant differences in QoL in GH deficient adult survivors of acute lymphoblastic leukaemia (ALL) neither before nor after 5 years of $\mathrm{GH}$ replacement. A considerable number of the present studies were part of the long term pharmacoepidemiological survey databases from Pfizer (KIMS $=$ Pfizer International Metabolic Database) and Eli Lilly (HypoCCS = Hypopituitary Control and Complications Study), each incorporating a large number of patients mainly for safety, but in a number of situations valuable efficacy data have also come out $[20,45,47$, $48,50-55,60]$. Although each individual publication deals with a particular data freeze from the database, and an increasing number of patients are included each year, it must be realized that the results of these studies are not completely independent and additive, since they are to some degree a repetition of outcomes from the same databases.

The reported improvements in QoL measurements were in some studies seen as early as 1 or 3 months after start of GH replacement therapy [43-45], but in other studies 12-24 months of GH replacement treatment were needed for an effect to be demonstrated [27]. Sustained improvements in QoL have been reported after 2 and 3 years of GH replacement $[40,42,46,50$, $51,53,55,60,61]$. These studies were in contrast to a recent report, which compared QoL scores of a group of patients receiving GH replacement therapy for GH deficiency for at least 1 year (mean 3 years of treatment) with scores from an age- and sex-matched control group without GH deficiency from the same geographical area. The GH treated group still had significant impairments in QoL scoring even after one year of therapy compared to the control population [62].

\section{EFFECTS OF GH DEFICIENCY AND GH THERAPY ON QOL IN SPECIFIC CONDITIONS}

GH production is declining with age after puberty, and the existence of a human somatopause has been discussed [63]. Toogood et al. demonstrated in an elegant study [64] 
Table 3. Quality of Life in Growth Hormone Deficient Adults

\begin{tabular}{|c|c|c|c|c|c|}
\hline Reference & GHD onset & $\mathbf{n}$ & Controls & Tests & Change in QoL in the GHD adults \\
\hline Abs et al. (1999) & $\mathrm{AO}+\mathrm{CO}$ & 1034 & Normal population & AGHDA & $\downarrow$ QoL \\
\hline Badia et al. (1998) & $\mathrm{AO}$ & 356 & $\begin{array}{l}963 \text { normals matched for } \\
\text { age, sex, education }\end{array}$ & AGHDA & $\downarrow$ QoL \\
\hline Baum et al. (1998) & $\mathrm{AO}$ & 41 & Normal population & $\begin{array}{c}\text { NHP } \\
\text { PGWB } \\
\text { GHQ } \\
\text { MMP1-2 }\end{array}$ & $=\mathrm{QoL}$ \\
\hline Blum et al. (2003) & $\mathrm{AO}+\mathrm{CO}$ & 957 & $\begin{array}{c}\text { Normal populations } \\
\text { corrected } \\
\text { For sex, age and country }\end{array}$ & QLS-H & $\downarrow$ QoL \\
\hline Björk et al. (1989) & $\mathrm{CO}$ & 23 & 47 normals & $\begin{array}{l}\text { NHP } \\
\text { PGWB }\end{array}$ & $\begin{array}{c}\uparrow \text { sleep problems } \\
\uparrow \text { social isolation } \\
\uparrow \text { physical mobility problems }\end{array}$ \\
\hline Burman et al. (1995) & $\mathrm{CO}+\mathrm{AO}$ & 36 & Normals & $\begin{array}{l}\text { HSCL } \\
\text { NHP }\end{array}$ & $\downarrow$ QoL proportional to duration of GHD \\
\hline Deijen et al. (1996) & $\begin{array}{l}31 \mathrm{MPHD} \\
17 \mathrm{IGHD}\end{array}$ & 48 & $\begin{array}{l}41 \text { normals matched } \\
\text { for age }\end{array}$ & $\begin{array}{c}\text { HSCL } \\
\text { POMS } \\
\text { Cognitive tests }\end{array}$ & $\begin{array}{l}\downarrow \text { IQ, memory, vigor } \\
\uparrow \text { anxiety (MPHD) }\end{array}$ \\
\hline $\begin{array}{l}\text { Kendall-Taylor et al. } \\
\text { (2005) }\end{array}$ & $\mathrm{CO}+\mathrm{AO}$ & 393 & $\begin{array}{l}\text { General population } \\
\text { CO versus AO }\end{array}$ & $\begin{array}{l}\text { AGHDA } \\
\text { NHP }\end{array}$ & $\begin{array}{c}\downarrow \mathrm{QoL} \text { in } \mathrm{CO} \text { and } \mathrm{AO} \\
\mathrm{CO}>\mathrm{AO}\end{array}$ \\
\hline Lynch et al. (1994) & $\mathrm{CO}+\mathrm{AO}$ & 41 & 41 diabetics & $\begin{array}{c}\text { CIS } \\
\text { PAS } \\
\text { CPRS }\end{array}$ & $\begin{array}{c}\uparrow \text { depression } \\
\uparrow \text { personality disorders }\end{array}$ \\
\hline McGauley (1989) & Mostly AO & 24 & $\begin{array}{l}\text { Normals matched for } \\
\text { Sex, age, ethnicity, class } \\
\text { And residence }\end{array}$ & $\begin{array}{l}\text { NHP } \\
\text { PGWB }\end{array}$ & $\begin{array}{c}\downarrow \text { QoL (NHP) } \\
\uparrow \text { psychological distress } \\
\text { (PGWB) }\end{array}$ \\
\hline Moisey et al. (2009) & unknown & 18 & $\begin{array}{l}18 \text { age, sex and BMI } \\
\text { matched healthy controls }\end{array}$ & AGHDA & $\downarrow$ QoL \\
\hline Page et al. (1997) & $\begin{array}{l}\text { AO (hypopituitary } \\
\text { tumours) }\end{array}$ & 48 & $\begin{array}{l}\text { Mastoid surgery } \\
\text { patients }\end{array}$ & $\begin{array}{l}\text { GWBS } \\
\text { SF-36 }\end{array}$ & $=\mathrm{QoL}$ \\
\hline Rosen et al. (1994) & Mostly AO & 86 & $\begin{array}{l}\text { Normals matched for sex, } \\
\text { age, marital status, class }\end{array}$ & NHP & $\begin{array}{c}\downarrow \text { QoL, energy, sexlife } \\
\uparrow \text { emotional lability, social isolation }\end{array}$ \\
\hline Sandberg et al. (1998) & $\mathrm{CO}$ & 140 & Same-sex siblings & $\begin{array}{c}\text { SF-36 } \\
\text { SRS } \\
\text { SAS } \\
\text { BSI } \\
\text { Interview }\end{array}$ & $\begin{array}{c}\downarrow \text { general health } \\
=\text { emotional and mental health }\end{array}$ \\
\hline Stabler et al. (1992) & MPHD & 25 & $\begin{array}{l}\text { Normals matched for sex, } \\
\text { age, height and class }\end{array}$ & $\begin{array}{l}\text { Stress-reactivity, } \\
\text { psychometric } \\
\text { testing }\end{array}$ & $\begin{array}{c}\downarrow \text { openess } \\
\uparrow \text { assertiveness }\end{array}$ \\
\hline $\begin{array}{l}\text { Wallymahmed } \\
\text { et al. }(1999)\end{array}$ & $\mathrm{AO}$ & 57 & Age-matched diabetics & $\begin{array}{l}\text { HADS } \\
\text { SES } \\
\text { MFQ } \\
\text { LFS }\end{array}$ & $\begin{array}{c}\downarrow \text { QoL, self-esteem } \\
\downarrow \text { life fulfillment } \\
\uparrow \text { depression, fatigue } \\
\uparrow \text { anxiety }\end{array}$ \\
\hline Wexter et al. (2009) & $\begin{array}{l}\text { Mostly AO } \\
\text { (Acromegaly) }\end{array}$ & 26 & $\begin{array}{l}\text { GH-sufficient patients } \\
\text { with prior acromegaly }\end{array}$ & $\begin{array}{l}\text { AGHDA } \\
\text { SF-36 } \\
\text { SQ }\end{array}$ & $\downarrow$ QoL \\
\hline Wiren et al. (2000) & $\mathrm{AO}+\mathrm{CO}$ & 111 & 1448 normal population & AGHDA & $\downarrow$ QoL \\
\hline Wiren et al. (2001) & $\mathrm{CO}$ & 21 & GH-sufficient CO-GHD & $\begin{array}{l}\text { NHP } \\
\text { MACL } \\
\text { PGWB }\end{array}$ & $\begin{aligned} & \uparrow \text { anxiety } \\
= & \text { cognition }\end{aligned}$ \\
\hline Zenker et al. (2002) & Mostly AO & 98 & Normal population & $\begin{array}{l}\text { BDI } \\
\text { AS } \\
\text { LSC }\end{array}$ & $=\mathrm{QoL}$ \\
\hline
\end{tabular}

QoL, Quality of life; GHD, growth hormone deficiency; CO, childhood onset; AO, adult onset; IGHD, isolated GHD; MPHD, multiple pituitary hormone deficiencies; $n$, number of subjects with GHD; Tests used to quantify QoL (abbreviations from Table 2); $\uparrow,=, \downarrow$, change in QoL parameter compared to appropriate controls (Modified and updated from Hull and Harvey [11] with permission from the authors). 
Table 4. Effects of Growth Hormone Replacement Therapy on Quality of Life in Adults in Published Trials

\begin{tabular}{|c|c|c|c|c|c|c|c|}
\hline Baum et al. (1998) & $\mathrm{AO}$ & 40 & $2-6 \mu \mathrm{g} / \mathrm{kg}$ & $18 \mathrm{~m}$ & PCDB & $\begin{array}{c}\text { NHP } \\
\text { PGWB } \\
\text { GHQ } \\
\text { MMPI-2 } \\
\text { Cognition tests }\end{array}$ & $=$ cognition, $\mathrm{QoL}$ \\
\hline $\begin{array}{l}\text { McGauley et al. } \\
\text { (1989) }\end{array}$ & $\begin{array}{l}\text { Mostly } \\
\text { AO }\end{array}$ & 24 & $0.07 \mathrm{U} / \mathrm{kg}$ & $6 \mathrm{~m}$ & PCDB & $\begin{array}{l}\text { NHP } \\
\text { PGWB } \\
\text { GHQ }\end{array}$ & $\begin{array}{c}\uparrow \text { subjective well-being } \\
\uparrow \text { QoL (NHP) } \\
\uparrow \text { QoL (PGWB) }\end{array}$ \\
\hline Soares et al. (1999) & Not stated & 9 & $0.035 \mathrm{U} / \mathrm{kg}$ & $6 \mathrm{~m}$ & PCDB & $\begin{array}{c}\text { HDS } \\
\text { BDI } \\
\text { Cognitive tests }\end{array}$ & $\uparrow$ QoL, cognition \\
\hline Beshyah et al. (1995) & $\mathrm{AO}+\mathrm{CO}$ & 40 & $0.04 \mathrm{U} / \mathrm{kg}$ & $18 \mathrm{~m}$ & $\begin{array}{l}6 \mathrm{~m} \text { PCDB } \\
12 \mathrm{~m} \text { open }\end{array}$ & $\begin{array}{l}\text { CPRS } \\
\text { GHQ }\end{array}$ & $\begin{array}{c}\uparrow \mathrm{QoL} 12 \mathrm{~m}(\mathrm{CPRS}) \\
\uparrow \mathrm{QoL} 6 \mathrm{~m} \text { placebo (GHQ) }\end{array}$ \\
\hline Caroll et al. (1997) & Not stated & 42 & $\begin{array}{c}0.024(6 \mathrm{~m})- \\
0.012(6 \mathrm{~m}) \\
\mu \mathrm{g} / \mathrm{kg}\end{array}$ & $12 \mathrm{~m}$ & $\begin{array}{l}6 \mathrm{~m} \text { PCDB } \\
6 \mathrm{~m} \text { open }\end{array}$ & $\begin{array}{l}\text { NHP } \\
\text { PGWB }\end{array}$ & $\begin{array}{l}\uparrow \text { QoL on both scales } \\
\uparrow \text { NHP score in placebo }\end{array}$ \\
\hline Mahajan et al. (2004) & $\mathrm{AO}+\mathrm{CO}$ & 25 & $\begin{array}{c}0.04(1 \mathrm{~m})- \\
0.08(1 \mathrm{~m}) \\
\mathrm{mg} / \mathrm{kg} / \text { week } \\
\text { Normal IGF-I }\end{array}$ & $4 \mathrm{~m}$ & $\begin{array}{l}\text { PCDB } \\
\text { Cross over }\end{array}$ & $\begin{array}{l}\text { NHP } \\
\text { HDRS } \\
\text { MADRS }\end{array}$ & $\begin{array}{c}=\text { mobility, pain } \\
\uparrow \text { energy and emotional reactions } \\
\downarrow \text { social isolation, sleep disturbance } \\
\quad \downarrow \text { depression }\end{array}$ \\
\hline Mardh et al. (1994) & $\mathrm{AO}$ & 124 & Not stated & $12-18 \mathrm{~m}$ & $\begin{array}{l}\text { 6m PCDB } \\
6-12 \mathrm{~m} \text { open }\end{array}$ & $\begin{array}{l}\text { NHP } \\
\text { PGWB }\end{array}$ & $\begin{array}{l}\uparrow \text { QoL (NHP) } \\
\uparrow \text { Well-being }\end{array}$ \\
\hline $\begin{array}{l}\text { Urushihara et al. } \\
\qquad(2007)\end{array}$ & $\mathrm{AO}+\mathrm{CO}$ & 64 & $\begin{array}{c}0.021- \\
0.042-0.083 \\
\mathrm{mg} / \mathrm{kg} / \text { week, } \\
\text { Normal IGF-I }\end{array}$ & $16 \mathrm{~m}$ & $\begin{array}{l}24 \text { weeks } \\
\text { DBPC } \\
48 \text { weeks } \\
\text { Open }\end{array}$ & SF-36 & $\begin{array}{l}\uparrow \text { physical functioning and general } \\
\text { health (AO) } \\
\downarrow \text { social functioning and mental health } \\
\text { (CO) }\end{array}$ \\
\hline $\begin{array}{c}\text { Bengtsson et al. } \\
\text { (1993) }\end{array}$ & $\mathrm{AO}$ & 10 & $13-26 \mu \mathrm{g} / \mathrm{kg}$ & $6 \mathrm{~m}$ & $\begin{array}{l}\text { PCDB } \\
\text { Cross-over } \\
\end{array}$ & $\begin{array}{l}\text { CPRS } \\
\text { SCL-90 }\end{array}$ & $\begin{aligned} & \uparrow \mathrm{QoL}(\mathrm{CPRS}) \\
&= \mathrm{QoL}(\mathrm{SCL}-90) \\
&\end{aligned}$ \\
\hline $\begin{array}{l}\text { Degerblad et al. } \\
\text { (1990) }\end{array}$ & $\mathrm{AO}$ & 6 & $\begin{array}{l}0.07-0.09 \\
\mathrm{U} / \mathrm{kg}\end{array}$ & $3 \mathrm{~m}$ & $\begin{array}{c}\text { PCDB } \\
\text { Cross-over }\end{array}$ & $\begin{array}{c}\text { Mood } \\
\text { questionnaires } \\
\text { Psychometric } \\
\text { Testing } \\
\end{array}$ & $\begin{array}{c}=\text { mood, cognition } \\
\uparrow \text { vitality, mental } \\
\text { alertness }\end{array}$ \\
\hline $\begin{array}{l}\text { Whitehead et al. } \\
\text { (1992) }\end{array}$ & $\mathrm{AO}+\mathrm{CO}$ & 14 & $0.07 \mathrm{U} / \mathrm{kg}$ & $6 \mathrm{~m}$ & $\begin{array}{c}\text { PCDB } \\
\text { Cross-over }\end{array}$ & PGWB & $=\mathrm{QoL}$, but no $\uparrow$ IGF-I \\
\hline Cuneo et al. (1998) & $\begin{array}{l}\text { Mostly } \\
\text { AO }\end{array}$ & 166 & $\begin{array}{c}0.018(1 \mathrm{~m}) \\
0.036(11 \mathrm{~m}) \\
\mathrm{U} / \mathrm{kg}\end{array}$ & $12 \mathrm{~m}$ & $\begin{array}{c}6 \mathrm{~m} \text { PC } \\
6 \mathrm{~m} \text { open }\end{array}$ & $\begin{array}{c}\text { NHP } \\
\text { GHDQ } \\
\text { Social history }\end{array}$ & $\begin{array}{l}\uparrow \text { QoL 12m (NHP) } \\
=\text { QoL (GHDQ) }\end{array}$ \\
\hline Deijen et al. (1998) & $\mathrm{CO}$ (men) & 48 & $1-3 \mathrm{U} / \mathrm{m}^{2}$ & $24 \mathrm{~m}$ & $\mathrm{PC}$ & $\begin{array}{l}\text { Psychological } \\
\text { Testing } \\
\end{array}$ & $\begin{array}{c}=\text { well-being } \\
\uparrow \text { memory }\end{array}$ \\
\hline $\begin{array}{l}\text { Florkowski et al } \\
\text { (1998) }\end{array}$ & $\mathrm{AO}+\mathrm{CO}$ & 20 & $-0.035 \mathrm{U} / \mathrm{kg}$ & $3 \mathrm{~m}$ & $\begin{array}{l}\text { Randomized } \\
\text { PC, cross- } \\
\text { over }\end{array}$ & $\begin{array}{l}\text { DSQ } \\
\text { SCL-90 } \\
\text { SAS }\end{array}$ & $\underset{\text { groups }}{\uparrow \text { QoL placebo }+\mathrm{GH}}$ \\
\hline Giusti et al. (1998) & $\mathrm{AO}$ & 25 & $0.5-1 \mathrm{U}$ & $6 \mathrm{~m}$ & $\begin{array}{c}\text { Randomized } \\
\text { PC }\end{array}$ & $\begin{array}{l}\text { HDS } \\
\text { KSQ } \\
\end{array}$ & $\begin{array}{c}\uparrow \text { QoL (HDS) } \\
=\mathrm{KSQ}\end{array}$ \\
\hline Miller et al. (2010) & $\begin{array}{c}\mathrm{AO} \\
\text { (Acromegaly) }\end{array}$ & 30 & Normal IGF-I & $6 \mathrm{~m}$ & $\begin{array}{l}\text { Randomized } \\
\text { PC }\end{array}$ & $\begin{array}{l}\text { AGHDA } \\
\text { SF-36 } \\
\text { SQ }\end{array}$ & $\begin{array}{c}\uparrow \text { QoL (AGHDA) } \\
\uparrow \text { vitality, mental health, soc } \\
\text { functioning, general health } \\
\downarrow \text { role limitation }\end{array}$ \\
\hline
\end{tabular}




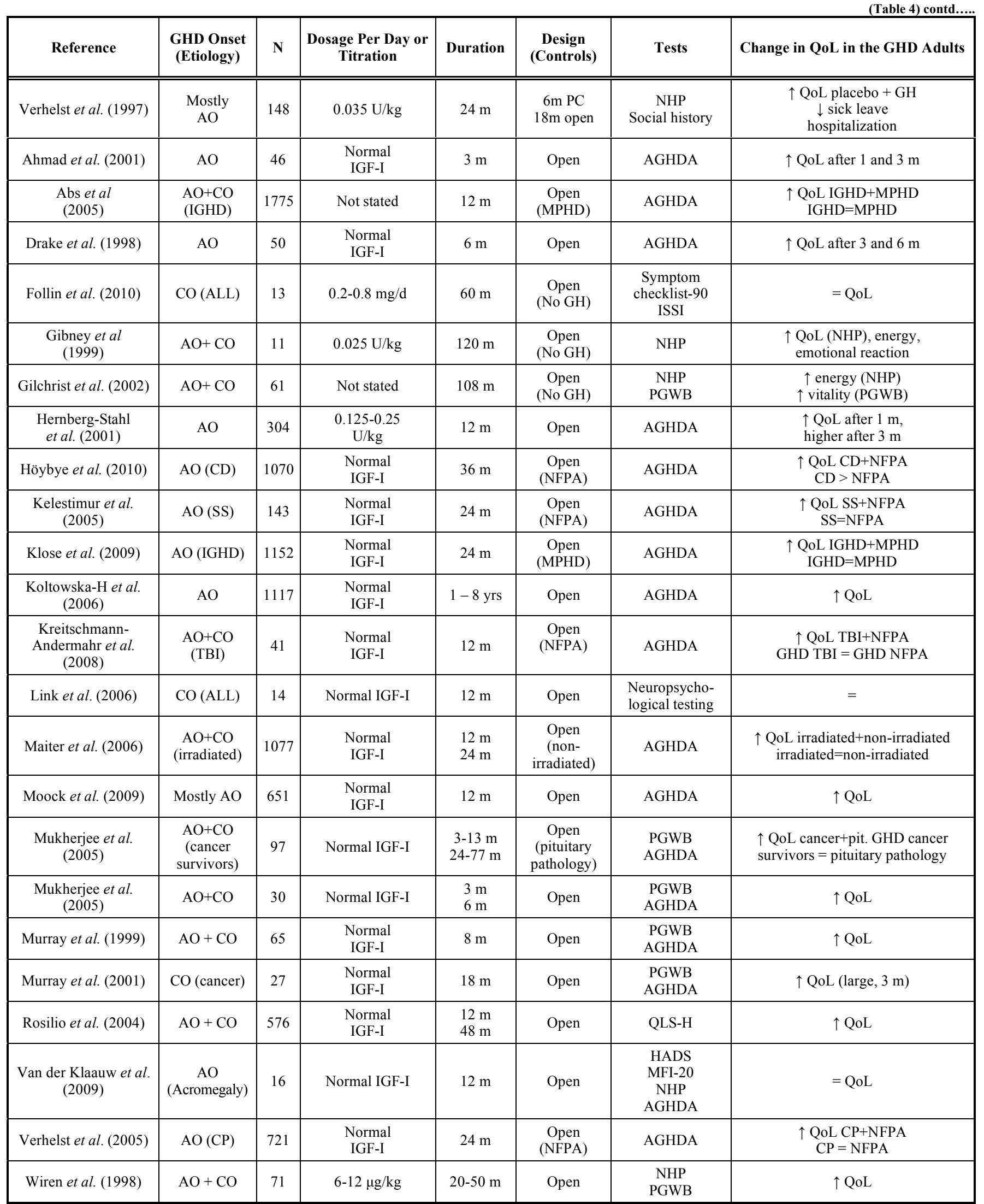

QoL, quality of life; GHD, growth hormone deficiency; AO, adult onset; CO, childhood onset; ALL, acute lymphoblastic leukaemia CP, craniopharyngeoma; CS, Cushing's Disease; NFPA, non-functional pituitary adenoma; SS, Sheehan's syndrome; TBI, traumatic brain injury; n, number of subjects; PC, placebo-controlled; PCDB, placebo-controlled, doubleblind; open, open label; Tests used to quantify QoL (abbreviations given in Table 2) $\uparrow,=, \downarrow$, change in QoL parameter in GH-treated patients and when available compared to controls (Modified and updated from Hull and Harvey [11] with permission from the authors). 
that a properly performed stimulation test for GH deficiency could distinguish between the GH response in healthy elderly persons above 65 years and that of hypopituitary patients with assumed GH deficiency. They [65] later demonstrated that these elderly GH deficient hypopituitary patients had indeed also a significantly unfavourable body composition and bone mineral content compared to healthy age matched counterparts. It was subsequently demonstrated that GH replacement therapy improved the QoL as assessed by AGHDA scores in these patients $>65$ years of age to the same degree as did young GH deficient patients [66, 67].

Li Voon Chong et al. [68] studied 27 elderly (mean age 73 years) patients with severe GH deficiency for 2 years without GH replacement and compared their QoL with an age matched group of elderly healthy individuals. They were investigated by SF-36, NHP, LFS, HADS, and MFQ, and although the QoL of the patients with GH deficiency did decrease during the 2 years so did it also in the healthy control group. Other measured variables such as body composition and lipids did not differ between the groups either. Their results have therefore raised some doubt about benefits of $\mathrm{GH}$ replacement in elderly people with $\mathrm{GH}$ deficiency. Most of the above mentioned studies have been performed in small heterogeneous groups of patients of different aetiologies. The larger surveillance databases such as KIMS and HypoCCS have provided a possibility to look into QoL in subgroups of patients. It has thus been possible to investigate if different causes of GH deficiency show differences in QoL both at baseline and in response to GH replacement. By such subdivisions it has been demonstrated in $665 \mathrm{GH}$ deficient adults, that patients with adult onset (AO) GH deficiency had a better responsiveness to GH replacement than childhood onset (CO) $\mathrm{GH}$ deficient patients [69]. They did, however, have a poorer QoL at baseline, thus indicating that the poorer the measure at baseline the better the potential for improvement by replacement.

It was later demonstrated that patients with isolated $\mathrm{GH}$ deficiency had similar baseline clinical presentation and responded equally well to GH replacement as patients with multiple pituitary hormone deficiency, suggesting that GH alone could be responsible for the improvement in QoL during $\mathrm{GH}$ replacement $[47,53]$.

From the KIMS database 351 patients with craniopharyngioma and severe GH deficiency were extracted. They had a mean AGHDA score of approx 11, equal in men and women, and largely similar to that of other GH deficient adults with other aetiologies. Their improvement was approximately 4 AGHDA scores after 2 years of GH replacement [50]. Noteworthy, these scores would not be sufficient to meet the aforementioned official NICE guidelines for $\mathrm{GH}$ replacement therapy. Other conditions where a similar responsiveness to $\mathrm{GH}$ replacement on QoL has been demonstrated are irradiated GH deficient patients compared to non- irradiated ones [51], cured Cushing's disease [55], traumatic brain injury [52], and Sheehan's syndrome. The latter is still a prevalent cause of GH deficiency in some countries, in the Northern-Western countries.
Mukherjee et al. [49] reported that QoL in adult GH deficient cancer survivors was comparable to that in $\mathrm{GH}$ deficient adults with pituitary pathologies, and improved with GH replacement in a similar manner, suggesting that QoL impairment in adult GH deficient cancer survivors is mainly related to GH deficiency rather than cancer diagnosis and treatment. In contrast, Link et al. [70] did not find any difference in baseline QoL comparing 44 adult survivors of childhood (ALL) and matched population controls.

The effect of growth hormone on the brain and thereby QoL is probably dual phased where both too much (acromegaly or overtreatment with $\mathrm{GH}$ ) and too little (GH deficiency) are detrimental. The adverse effect of $\mathrm{GH}$ overproduction as in acromegaly has been assessed by a number of QoL measures [71, 72], but the interpretation is often difficult since GH may influence the QoL through other effects than directly on the brain, such as on the sleep pattern [73] e.g. by obstruction or by an interaction with melatonin [74] or by low self esteem due to disfiguring of the patients with longstanding disease [71]. Recently, it was demonstrated that 40 previously acromegalic patients with GH deficiency consequent to treatment for acromegaly were similarly affected with similar reductions in QoL by AGHDA as were 1392 patients with GH deficiency of other aetiologies (mainly non-functioning adenomas) [75]. Furthermore, the GH deficient acromegalic patients had similar beneficial effects from GH replacement therapy as did GH deficient patients of other aetiologies. These results from the KIMS database were in keeping with results from a recent randomised placebo controlled study including 30 patients with cured acromegaly showing an improvement in QoL after six months treatment [38].

\section{THERAPEUTIC MECHANISMS OF GH REPLAC- EMENT}

The mechanism by which GH works to improve QoL is not very clear. Some of the effects mentioned below have previously been reviewed [11]. A direct effect on the brain is one possibility, which is dealt with elsewhere. GH crosses the blood barrier and treatment with $\mathrm{GH}$ increases the concentration in the spinal fluid of both $\mathrm{GH}$ and several neurotransmitters [76]. Also GH receptors have been demonstrated in the brain, which increases the likelihood that a direct effect on brain growth and development, as well as on neural repair, takes place. Furthermore, the brain is considered to be a site of GH production and action, and it therefore seems likely that GH deficiency would have detrimental effects on cognition and mood and consequently on QoL. On the other hand, GH deficiency has a number of well documented somatic effects on metabolism, cardiovascular function, pulmonary function, muscle strength, body composition, sweat secretion, immune function and bones, all of which are more or less completely reverted after $\mathrm{GH}$ replacement. Therefore, a number of the items in the QoL questionnaires that has to do with e.g. energy and physical mobility would impact on the QoL scores. It is also very possible, that the changes in body composition with increased body fat percentage and reduced muscle mass in GH deficiency can contribute to a reduced self-perceived 
QoL, as may also the constant change in fluid homeostasis with a consequent symptomatic reduction of blood and plasma volume. Finally, decreased sweating ability results in impaired heat dissipation [77], which together with low muscle strength can impair the person's self-esteem due to physical performance difficulties and reduced exercise capacity. Therefore, the impact of GH status on physical clinical indices such as height, body composition, metabolism, cardiovascular and bone health may be responsible for some of the $\mathrm{GH}$ dependent QoL measurements. The somatic responses to $\mathrm{GH}$ replacement are heterogeneous and might therefore also reflect a heterogeneity of QoL responses. Finally, an interaction with other hypothalamo-pituitary hormone deficiencies and replacements may be in play. For instance, GH has a welldocumented effect on the thyroid axis by increasing the peripheral conversion of thyroxine to triiodothyronine (T3), which is the active thyroid hormone at the peripheral cellular level $[78,79]$. A low T3 in GH deficiency may therefore contribute to a low activity level and thus a poor QoL, which should be reverted by GH replacement. A correlation between the T3 concentration and QoL has, however, not been proven.

\section{COST BENEFIT CONSIDERATIONS}

Calculating the cost of GH replacement treatment is rather complicated, since the direct cost of GH is only a small part of the equation. Furthermore, most patients with GH deficiency, whether started in childhood or adulthood, have other disease- related conditions such as other pituitary hormone deficiencies or consequences of a treated disease such as Cushing's disease or irradiated intra-cranial childhood cancer. In the other extreme some adult patients have childhood onset idiopathic isolated GH deficiency with very limited disease burden. The estimated morbidity of patients with GH deficiency is therefore very heterogeneous and highly dependent on the aetiology of the disease. A few earlier studies have estimated increased cost of health care consumption in patients with untreated GH deficiency [8083]. Only few studies have attempted to calculate the total costs of GH replacement (reviewed by Radcliffe et al. [84]). In one of the studies [45] results from patients in the KIMS database were used, applying a health related QoL questionnaire (AGHDA), along with a needs-based questionnaire (KIMS Patient Life Situation Form). When being $\mathrm{GH}$ deficient and before receiving GH replacement approximately $20 \%$ of 304 patients received a disability pension. QoL in the patients receiving pension was more impaired than in those working or those retiring normally. During GH replacement therapy the use of specific health care resources, such as days of sick leave, visits to the doctor, hospital days and assistance with daily activities, decreased. At the same time the QoL increased as evidenced by increased AGHDA scores. These results have been substantiated by publication of similar calculations with similar outcome from a single country (Sweden) [61]. They studied 237 Swedish patients enrolled into KIMS, and who had been treated for 3 years with GH. The number of days of sick leave, days in hospital and visits to the doctor were all reduced after GH replacement. At the same time leisure-time physical activity and general satisfaction with physical activity level increased, as did also AGHDA scores. After 3 years the treated GH deficient patients had the same number of days of sick leave as before start of treatment, but all the other items remained improved. The findings from the heterogeneous group of GH deficient patients from different countries [45] could thus be confirmed in a homogeneous patient population from Sweden [61]. It was later shown that despite some differences in treatment strategies, healthcare utilization was essentially similar in the healthcare environment of Western European countries [85].

\section{CONCLUSION}

As indicated above many of the studies performed to assess QoL and GH replacement in hypopituitary patients either do not have a sufficient follow-up period, are uncontrolled, using supra physiological $\mathrm{GH}$ doses or are using inappropriate QoL instruments. Despite this, there is a growing body of evidence that QoL is indeed impaired in GH deficient patients and that GH replacement induces a sustained improvement or normalisation. GH may improve QoL via neurological mechanisms. However, the beneficial effect of GH replacement in hypopituitary GH deficient patients on cardiovascular, reproductive, metabolic and immune functions may have an additional impact on the improved QoL. GH therapy does not improve QoL in every $\mathrm{GH}$ deficient individual. Dosage of $\mathrm{GH}$ is important as no improvement in QoL may be expected if the GH dosage is sub-optimal. However, it may be difficult to determine the optimal dose based on weight, surface, gender and correct titration according to the plasma IGF-I concentration. Degree of impairment of QoL is also important since no improvement can be expected in a GH deficient patient that has not developed the full phenotype e.g. shortly after surgery. Yet, many clinical guidelines rely on QoL measures both for the indication for GH replacement in the individual patient and also treatment follow-up. A combination of disease-specific and generic instruments must be advised, and a proper registration in each country of the QoL score by each particular questionnaire in a comparative healthy control population is mandatory. It will also be important in the future to focus on subgroups of patients that may benefit more from GH replacement than others. With proper instruments GH replacement does seem to decrease health care consumption in parallel with improvements in QoL. This needs to be translated into a full calculation of costeffectiveness of GH-replacement in each country, not only considering the price of $\mathrm{GH}$ but also the health care related costs such as visits to the doctor, hospitalization, daily assistance from others etc.

\section{CONFLICT OF INTEREST}

The authors confirm that this article content has no conflicts of interest.

\section{ACKNOWLEDGEMENTS}

UF-R has received a grant from Arvid Nilsson's Foundation. 


\section{REFERENCES}

[1] Hankinson SE, Willett WC, Colditz GA, et al. Circulating concentrations of insulin-like growth factor-I and risk of breast cancer. Lancet 1998; 351: 1393-6.

[2] Shaneyfelt T, Husein R, Bubley G, et al. Hormonal predictors of prostate cancer: a meta-analysis. J Clin Oncol 2000; 18: 847-53.

[3] Gharib H, Cook DM, Saenger PH, et al. American Association of Clinical Endocrinologists medical guidelines for clinical practice for growth hormone use in adults and children--2003 update. Endocr Pract 2003; 9: 64-76.

[4] National institute for Clinical Excellence. Human growth hormone (somatropin) in adults with growth hormone deficiency. Technology Appraisal 64. 2003. Available at: www.nice.org.uk

[5] McKenna SP, Doward LC, Alonso J, et al. The QoL-AGHDA: an instrument for the assessment of quality of life in adults with growth hormone deficiency. Qual Life Res 1999; 8: 373-83.

[6] Guyatt GH, Feeny DH, Patrick DL. Measuring health-related quality of life. Ann Intern Med 1993; 118: 622-9.

[7] Wilson IB, Cleary PD. Linking clinical variables with healthrelated quality of life. A conceptual model of patient outcomes. JAMA 1995; 273: 59-65.

[8] Ware JE Jr. The status of health assessment 1994. Annu Rev Public Health 1995; 16: 327-54.

[9] Testa MA, Simonson DC. Assesment of quality-of-life outcomes. N Engl J Med 1996; 334: 835-40.

[10] Spilker B. Quality of life and pharmacoeconomics in clinical trials. $2^{\text {nd }}$ ed. Philadelphia: Lippencott-Raven Publishers 1996.

[11] Hull KL, Harvey S. Growth hormone therapy and Quality of Life: possibilities, pitfalls and mechanisms. J Endocrinol 2003; 179: 31133.

[12] Holmes SJ, McKenna S, Doward LC, et al. Development of a questionnaire to assess the quality of life of adults with growth hormone deficiency. Endocrinol Metab 1995; 2: 63-9.

[13] Monson JP. Application of a disease-specific, quality-of-life measure (QoL-AGHDA) in growth hormone-deficient adults and a random population sample in sweden: validation of the measure by rasch analysis. Clin Endocrinol (Oxf) 2000; 52: 141-2.

[14] Consensus guidelines for the diagnosis and treatment of adults with growth hormone deficiency: summary statement of the Growth Hormone Research Society Workshop on Adult Growth Hormone Deficiency. J Clin Endocrinol Metab 1998; 83: 379-81.

[15] Baum HB, Katznelson L, Sherman JC, et al. Effects of physiological growth hormone $(\mathrm{GH})$ therapy on cognition and quality of life in patients with adult-onset GH deficiency. J Clin Endocrinol Metab 1998; 83: 3184-9.

[16] Zenker S, Haverkamp F, Klingmuller D. Growth hormone deficiency in pituitary disease: relationship to depression, apathy and somatic complaints. Eur J Endocrinol 2002; 147: 165-71.

[17] Page RC, Hammersley MS, Burke CW, et al. An account of the quality of life of patients after treatment for non-functioning pituitary tumours. Clin Endocrinol (Oxf) 1997; 46: 401-6.

[18] McMillan CV, Bradley C, Gibney J, et al. Psychological effects of withdrawal of growth hormone therapy from adults with growth hormone deficiency. Clin Endocrinol (Oxf) 2003; 59: 467-75.

[19] Rosen T, Wiren L, Wilhelmsen L, et al. Decreased psychological well-being in adult patients with growth hormone deficiency. Clin Endocrinol (Oxf) 1994; 40: 111-6.

[20] Koltowska-Haggstrom M, Mattsson AF, Monson JP, et al. Does long-term GH replacement therapy in hypopituitary adults with $\mathrm{GH}$ deficiency normalise quality of life? Eur J Endocrinol 2006; 155: 109-19.

[21] Koltowska-Haggstrom M, Hennessy S, Mattsson AF, et al. Quality of life assessment of growth hormone deficiency in adults (QoLAGHDA): comparison of normative reference data for the general population of England and Wales with results for adult hypopituitary patients with growth hormone deficiency. Horm Res 2005; 64: 46-54.

[22] Wiren L, Whalley D, McKenna S, et al. Application of a diseasespecific, quality-of-life measure (QoL-AGHDA) in growth hormone-deficient adults and a random population sample in Sweden: validation of the measure by rasch analysis. Clin Endocrinol (Oxf) 2000; 52: 143-52.

[23] Blum WF, Shavrikova EP, Edwards DJ, et al. Decreased quality of life in adult patients with growth hormone deficiency compared with general populations using the new, validated, self-weighted questionnaire, questions on life satisfaction hypopituitarism module. J Clin Endocrinol Metab 2003; 88: 4158-67.

[24] McGauley GA. Quality of life assessment before and after growth hormone treatment in adults with growth hormone deficiency. Acta Paediatr Scand Suppl 1989; 356: 70-2.

[25] Bengtsson BA, Eden S, Lonn L, et al. Treatment of adults with growth hormone $(\mathrm{GH})$ deficiency with recombinant human $\mathrm{GH}$. J Clin Endocrinol Metab 1993; 76: 309-17.

[26] Mardh G, Lundin K, Borg G, et al. Growth hormone replacement therapy in adult hypopituitary patients with growth hormone deficiency: combined data from 12 European placebo-controlled trials. Endocrinol Metab 1994; 1: 43-9.

[27] Beshyah SA, Freemantle C, Shahi M, et al. Replacement treatment with biosynthetic human growth hormone in growth hormonedeficient hypopituitary adults. Clin Endocrinol (Oxf) 1995; 42: 7384.

[28] Burman P, Broman JE, Hetta J, et al. Quality of life in adults with growth hormone $(\mathrm{GH})$ deficiency: response to treatment with recombinant human $\mathrm{GH}$ in a placebo-controlled 21-month trial. J Clin Endocrinol Metab 1995; 80: 3585-90.

[29] Attanasio AF, Lamberts SW, Matranga AM, et al. Adult growth hormone $(\mathrm{GH})$-deficient patients demonstrate heterogeneity between childhood onset and adult onset before and during human GH treatment. Adult Growth Hormone Deficiency Study Group. J Clin Endocrinol Metab 1997; 82: 82-8.

[30] Urushihara H, Fukuhara S, Tai S, et al. Heterogeneity in responsiveness of perceived quality of life to body composition changes between adult- and childhood-onset Japanese hypopituitary adults with GH deficiency during $\mathrm{GH}$ replacement. Eur J Endocrinol 2007; 156: 637-45.

[31] Carroll PV, Littlewood R, Weissberger AJ, et al. The effects of two doses of replacement growth hormone on the biochemical, body composition and psychological profiles of growth hormonedeficient adults. Eur J Endocrinol 1997; 137: 146-53.

[32] Verhelst J, Abs R, Vandeweghe M, et al. Two years of replacement therapy in adults with growth hormone deficiency. Clin Endocrinol (Oxf) 1997; 47: 485-94.

[33] Wallymahmed ME, Foy P, MacFarlane IA. The quality of life of adults with growth hormone deficiency: comparison with diabetic patients and control subjects. Clin Endocrinol (Oxf) 1999; 51: 3338.

[34] Cuneo RC, Judd S, Wallace JD, et al. The Australian Multicenter Trial of Growth Hormone (GH) Treatment in GH-Deficient Adults. J Clin Endocrinol Metab 1998; 83: 107-16.

[35] Florkowski CM, Stevens I, Joyce P, et al. Growth hormone replacement does not improve psychological well-being in adult hypopituitarism: a randomized crossover trial. Psychoneuroendocrinology 1998; 23: 57-63.

[36] Soares CN, Musolino NR, Cunha NM, et al. Impact of recombinant human growth hormone (RH-GH) treatment on psychiatric, neuropsychological and clinical profiles of $\mathrm{GH}$ deficient adults. A placebo-controlled trial. Arq Neuropsiquiatr 1999; 57: 182-9.

[37] Mahajan T, Crown A, Checkley S, et al. Atypical depression in growth hormone deficient adults, and the beneficial effects of growth hormone treatment on depression and quality of life. Eur $\mathrm{J}$ Endocrinol 2004; 151: 325-32.

[38] Miller KK, Wexler T, Fazeli P, et al. Growth hormone deficiency after treatment of acromegaly: a randomized, placebo-controlled study of growth hormone replacement. J Clin Endocrinol Metab 2010; 95: 567-77.

[39] Bjork S, Jonsson B, Westphal O, et al. Quality of life of adults with growth hormone deficiency: a controlled study. Acta Paediatr Scand Suppl 1989; 356: 55-9.

[40] Wiren L, Bengtsson BA, Johannsson G. Beneficial effects of longterm $\mathrm{GH}$ replacement therapy on quality of life in adults with $\mathrm{GH}$ deficiency. Clin Endocrinol (Oxf) 1998; 48: 613-20.

[41] Drake WM, Coyte D, Camacho-Hubner C, et al. Optimizing growth hormone replacement therapy by dose titration in hypopituitary adults. J Clin Endocrinol Metab 1998; 83: 3913-9.

[42] Gibney J, Wallace JD, Spinks T, et al. The effects of 10 years of recombinant human growth hormone $(\mathrm{GH})$ in adult $\mathrm{GH}$-deficient patients. J Clin Endocrinol Metab 1999; 84: 2596-602. 
[43] Murray RD, Skillicorn CJ, Howell SJ, et al. Influences on quality of life in GH deficient adults and their effect on response to treatment. Clin Endocrinol (Oxf) 1999; 51: 565-73.

[44] Ahmad AM, Hopkins MT, Thomas J, et al. Body composition and quality of life in adults with growth hormone deficiency; effects of low-dose growth hormone replacement. Clin Endocrinol (Oxf) 2001; 54: 709-17.

[45] Hernberg-Stahl E, Luger A, Abs R, et al. Healthcare consumption decreases in parallel with improvements in quality of life during GH replacement in hypopituitary adults with GH deficiency. J Clin Endocrinol Metab 2001; 86: 5277-81.

[46] Gilchrist FJ, Murray RD, Shalet SM. The effect of long-term untreated growth hormone deficiency (GHD) and 9 years of GH replacement on the quality of life (QoL) of GH-deficient adults. Clin Endocrinol (Oxf) 2002; 57: 363-70.

[47] Abs R, Mattsson AF, Bengtsson BA, et al. Isolated growth hormone $(\mathrm{GH})$ deficiency in adult patients: baseline clinical characteristics and responses to $\mathrm{GH}$ replacement in comparison with hypopituitary patients. A sub-analysis of the KIMS database. Growth Horm IGF Res 2005; 15: 349-59.

[48] Kelestimur F, Jonsson P, Molvalilar S, et al. Sheehan's syndrome: baseline characteristics and effect of 2 years of growth hormone replacement therapy in 91 patients in K. Eur J Endocrinol 2005; 152: 581-7.

[49] Mukherjee A, Tolhurst-Cleaver S, Ryder WD, et al. The characteristics of quality of life impairment in adult growth hormone (GH)deficient survivors of cancer and their response to GH replacement therapy. J Clin Endocrinol Metab 2005; 90: 1542-9.

[50] Verhelst J, Kendall-Taylor P, Erfurth EM, et al. Baseline characteristics and response to 2 years of growth hormone $(\mathrm{GH})$ replacement of hypopituitary patients with GH deficiency due to adult-onset craniopharyngioma in comparison with patients with nonfunctioning pituitary adenoma: data from KIMS (Pfizer International Metabolic Database). J Clin Endocrinol Metab 2005; 90: 4636-43

[51] Maiter D, Abs R, Johannsson G, et al. Baseline characteristics and response to $\mathrm{GH}$ replacement of hypopituitary patients previously irradiated for pituitary adenoma or craniopharyngioma: data from the Pfizer International Metabolic Database. Eur J Endocrinol 2006; 155: 253-60.

[52] Kreitschmann-Andermahr I, Poll EM, Reineke A, et al. Growth hormone deficient patients after traumatic brain injury--baseline characteristics and benefits after growth hormone replacement--an analysis of the German KIMS database. Growth Horm IGF Res 2008; $18: 472-8$.

[53] Klose M, Jonsson B, Abs R, et al. From isolated GH deficiency to multiple pituitary hormone deficiency: an evolving continuum - a KIMS analysis. Eur J Endocrinol 2009; 161(Suppl 1): S75-S83.

[54] Moock J, Albrecht C, Friedrich N, et al. Health-related quality of life and IGF-1 in GH-deficient adult patients on GH replacement therapy: analysis of the German KIMS data and the Study of Health in Pomerania. Eur J Endocrinol 2009; 160: 17-24.

[55] Hoybye C, Ragnarsson O, Jonsson PJ, et al. Clinical features of GH deficiency and effects of 3 years of GH replacement in adults with controlled Cushing's disease. Eur J Endocrinol 2010; 162: 677-84.

[56] Degerblad M, Almkvist O, Grunditz R, et al. Physical and psychological capabilities during substitution therapy with recombinant growth hormone in adults with growth hormone deficiency. Acta Endocrinol (Copenh) 1990; 123: 185-93.

[57] Whitehead HM, Boreham C, McIlrath EM, et al. Growth hormone treatment of adults with growth hormone deficiency: results of a 13-month placebo controlled cross-over study. Clin Endocrinol (Oxf) 1992; 36: 45-52.

[58] Giusti M, Meineri I, Malagamba D, et al. Impact of recombinant human growth hormone treatment on psychological profiles in hypopituitary patients with adult-onset growth hormone deficiency. Eur J Clin Invest 1998; 28: 13-9.

[59] Deijen JB, de BH, van d, V. Cognitive changes during growth hormone replacement in adult men. Psychoneuroendocrinology 1998; 23: 45-55.

[60] Rosilio M, Blum WF, Edwards DJ, et al. Long-term improvement of quality of life during growth hormone $(\mathrm{GH})$ replacement therapy in adults with GH deficiency, as measured by questions on life satisfaction-hypopituitarism (QLS-H). J Clin Endocrinol Metab 2004; 89: 1684-93.

[61] Svensson J, Mattsson A, Rosen T, et al. Three-years of growth hormone (GH) replacement therapy in GH-deficient adults: effects on quality of life, patient-reported outcomes and healthcare consumption. Growth Horm IGF Res 2004; 14: 207-15.

[62] Malik IA, Foy P, Wallymahmed M, et al. Assessment of quality of life in adults receiving long-term growth hormone replacement compared to control subjects. Clin Endocrinol (Oxf) 2003; 59: 7581.

[63] Toogood AA, O'Neill PA, Shalet SM. Beyond the somatopause: growth hormone deficiency in adults over the age of 60 years. J Clin Endocrinol Metab 1996; 81: 460-5.

[64] Toogood AA, Jones J, O'Neill PA, et al. The diagnosis of severe growth hormone deficiency in elderly patients with hypothalamicpituitary disease. Clin Endocrinol (Oxf) 1998; 48: 569-76.

[65] Toogood AA. Growth hormone (GH) status and body composition in normal ageing and in elderly adults with GH deficiency. Horm Res 2003; 60: 105-11.

[66] Monson JP, Abs R, Bengtsson BA, et al. Growth hormone deficiency and replacement in elderly hypopituitary adults. KIMS Study Group and the KIMS International Board. Pharmacia and Upjohn International Metabolic Database. Clin Endocrinol (Oxf) 2000; 53: 281-9.

[67] Feldt-Rasmussen U, Wilton P, Jonsson P. Aspects of growth hormone deficiency and replacement in elderly hypopituitary adults. Growth Horm IGF Res 2004; 14 (Suppl A): S51-S58.

[68] Li Voon Chong JS, Groves T, Foy P, et al. Elderly people with hypothalamic-pituitary disease and untreated GH deficiency: clinical outcome, body composition, lipid profiles and quality of life after 2 years compared to controls. Clin Endocrinol (Oxf) 2002; 56: $175-81$.

[69] Bengtsson BA, Abs R, Bennmarker $\mathrm{H}$, et al. The effects of treatment and the individual responsiveness to growth hormone (GH) replacement therapy in $665 \mathrm{GH}$-deficient adults. KIMS Study Group and the KIMS International Board. J Clin Endocrinol Metab 1999; 84: 3929-35.

[70] Link K, Moell C, Osterberg K, et al. Adult survivors of childhood acute lymphoblastic leukaemia with GH deficiency have normal self-rated quality of life but impaired neuropsychological performance 20 years after cranial irradiation. Clin Endocrinol (Oxf) 2006; 65: 617-25.

[71] Pantanetti P, Sonino N, Arnaldi G, et al. Self image and quality of life in acromegaly. Pituitary $2002 ; 5: 17-9$.

[72] Biermasz NR, van Thiel SW, Pereira AM, et al. Decreased quality of life in patients with acromegaly despite long-term cure of growth hormone excess. J Clin Endocrinol Metab 2004; 89: 5369-76.

[73] Astrom C, Lindholm J. Growth hormone-deficient young adults have decreased deep sleep. Neuroendocrinology 1990; 51: 82-4.

[74] Sinisi AA, Pasquali D, D'Apuzzo A, et al. Twenty-four hour melatonin pattern in acromegaly: effect of acute octreotide administration. J Endocrinol Invest 1997; 20: 128-33.

[75] Feldt-Rasmussen U, Abs R, Bengtsson BA, et al. Growth hormone deficiency and replacement in hypopituitary patients previously treated for acromegaly or Cushing's disease. Eur J Endocrinol 2002; 146: 67-74.

[76] Johansson JO, Larson G, Andersson M, et al. Treatment of growth hormone-deficient adults with recombinant human growth hormone increases the concentration of growth hormone in the cerebrospinal fluid and affects neurotransmitters. Neuroendocrinology 1995; 61: 57-66.

[77] Juul A, Behrenscheer A, Tims T, et al. Impaired thermoregulation in adults with growth hormone deficiency during heat exposure and exercise. Clin Endocrinol (Oxf) 1993; 38: 237-44.

[78] Burman P, Hetta J, Wide L, et al. Growth hormone treatment affects brain neurotransmitters and thyroxine [see comment]. Clin Endocrinol (Oxf) 1996; 44: 319-24.

[79] Jorgensen JO, Moller J, Laursen $\mathrm{T}$, et al. Growth hormone administration stimulates energy expenditure and extrathyroidal conversion of thyroxine to triiodothyronine in a dose-dependent manner and suppresses circadian thyrotrophin levels: studies in GH-deficient adults. Clin Endocrinol (Oxf) 1994; 41: 609-14.

[80] Ehrnborg C, Hakkaart-Van RL, Jonsson B, et al. Cost of illness in adult patients with hypopituitarism. Pharmacoeconomics 2000; 17: 621-8. 
[81] Hakkaart-Van RL, Beckers A, Stevenaert A, et al. The burden of illness of hypopituitary adults with growth hormone deficiency. Pharmacoeconomics 1998; 14: 395-403.

[82] Jonsson B, Nilsson B. The impact of pituitary adenoma on morbidity. Increased sick leave and disability retirement in a crosssectional analysis of Swedish national data. Pharmacoeconomics 2000; 18: 73-81.

[83] Sanmarti A, Lucas A, Hawkins F, et al. Observational study in adult hypopituitary patients with untreated growth hormone deficiency (ODA study). Socio-economic impact and health status.
Collaborative ODA (Observational GH Deficiency in Adults) Group. Eur J Endocrinol 1999; 141: 481-9.

[84] Radcliffe DJ, Pliskin JS, Silvers JB, et al. Growth hormone therapy and quality of life in adults and children. Pharmacoeconomics 2004; 22: 499-524

[85] Saller B, Mattsson AF, Kann PH, et al. Healthcare utilization, quality of life and patient-reported outcomes during two years of GH replacement therapy in GH-deficient adults--comparison between Sweden, The Netherlands and Germany. Eur J Endocrinol 2006; 154: 843-50.

(C) Klose et al.; Licensee Bentham Open.

This is an open access article licensed under the terms of the Creative Commons Attribution Non-Commercial License (http://creativecommons.org/licenses/by$\mathrm{nc} / 3.0 /$ ) which permits unrestricted, non-commercial use, distribution and reproduction in any medium, provided the work is properly cited. 